\title{
Relationships among recent Alpine Cladocera remains and their environment: implications for climate-change studies
}

\author{
Christian Kamenik - Krystyna Szeroczyńska • \\ Roland Schmidt
}

(C) Springer Science+Business Media B.V. 2007

\begin{abstract}
Our objective was to assess the potential of Cladocera from mountain lakes for climate reconstruction. We related Cladocera from surface sediments of Alpine lakes (1,502-2,309 m asl) to 29 abiotic environmental variables using statistical methods. The environmental dataset included water chemistry, lake depth, and bi-hourly water-temperature logs, which were used to assess mean monthly water temperatures, dates of freezing and breakup, spring and autumn mixing. We found 14 different Cladocera of the families Bosminidae, Daphniidae, and Chydoridae. Lakes without Cladocera (eight lakes) were cold and/or ultra-oligotrophic, whereas lakes with planktonic and littoral Cladocera (19 lakes) were warmer and/or less oligotrophic. Lakes with only littoral Cladocera (18 lakes) had intermediate water temper-
\end{abstract}

Guest editor: Piet Spaak

Cladocera: Proceedings of the 7th International Symposium on Cladocera

C. Kamenik ( $\square)$

Institute of Geography, University of Bern, Erlachstrasse 9a, Bern 3012, Switzerland

e-mail: christian.kamenik@giub.unibe.ch

\section{K. Szeroczyńska}

Institute of Geological Sciences, Polish Academy of Sciences, Twarda 51/55, Warsaw 00-818, Poland

R. Schmidt

Institute of Limnology, Austrian Academy of Sciences,

Mondseestraße 9, Mondsee 5310, Austria atures/trophy. Changes in Cladocera assemblages were related to changes in climate, nutrients, and/or alkalinity. We found a climate threshold at which Bosminidae disappeared in $95 \%$ of the lakes. For climate-change research, we propose studying Cladocera along transects that include climatic thresholds.

Keywords Lake mixing - Climate - Threshold · Alps · Mountain lakes

\section{Introduction}

Lake sediments are valuable climate archives (e.g., Moberg et al., 2005). Climate data beyond the instrumental period are essential to understand the climate system and to forecast future climate (Bradley, 2000). Sedimentary climate proxies, such as Cladocera, chironomids, diatoms, or chrysophyte remains, have been used to reconstruct climate throughout the Holocene, and beyond (e.g., Lotter et al., 2000; Heiri et al., 2003; Schmidt et al., 2004a; Kamenik \& Schmidt, 2005). Combining the climate signals obtained from sedimentary proxies by using a 'multi-proxy approach' helps improving the reliability of climate reconstructions (Battarbee, 2000).

Cladocera (Crustacea) are an essential component of the zooplankton and littoral zoobenthos of mountain lakes (e.g., Winder et al., 2001; Manca \& Armiraglio, 2002). Cladocera leave well preserved chitinous remains in lake sediments, which are often abundant 
and diverse; and most of these remains can be identified to the specific level (Frey, 1986; Hofmann, 1987; Korhola \& Rautio, 2001). Among the Cladocera preserved in lake sediments, Bosminidae and Daphniidae occur in the pelagic zone, while Chydoridae mainly represent littoral benthos (Frey, 1988). In northtemperate lakes, this habitat specificity was used to infer climate-related water-level changes (e.g., Sarmaja-Korjonen et al., 2003; Korhola et al., 2005). Contrary to this habitat specificity, Cladocera are not stenothermal (Meijering, 1983). Nevertheless, Cladocera assemblages were shown to respond to major climatic shifts, such as the Younger Dryas (e.g., Hofmann, 2000; Milecka \& Szeroczyńska, 2005). They show changes along latitudinal and altitudinal gradients (e.g., Harmsworth, 1968; Lotter et al., 1997). In Norway and Finnish Lapland, altitude appeared to be the main factor driving crustacean species compositions, either directly via dispersal and colonization abilities or indirectly via temperature and the amount of aquatic vegetation (Sandøy \& Nilssen, 1986; Rautio, 1998, 2001; Korhola, 1999). Lotter et al. (1997) and Korhola (1999) showed that air or water temperature had a statistically significant effect on Cladocera assemblages from Alpine and sub-arctic lakes sampled along steep ecoclimatic gradients, probably because the species differ in their temperature-tolerance. Cladocera were used for quantitative temperature reconstructions during the late-Glacial/early-Holocene (Duigan \& Birks, 2000; Lotter et al., 2000).

Environmental changes that are not related to climate, such as eutrophication, acidification, or habitat modification, can hamper Cladocera-based climate reconstruction (e.g., Sarmaja-Korjonen \& Alhonen, 1999; Duigan \& Birks, 2000; Szeroczyńska, 2002; Hofmann, 2003). Besides climate and lakelevel changes, Cladocera were shown to respond to e.g., variations in the acid-base balance, or in ion and nutrient concentrations (e.g., Lotter et al., 1997, 1998; Korhola, 1999). Changes in the catchment (e.g., deforestation) played a critical role for Cladocera assemblages during the Holocene (Lotter \& Birks, 2003). Cladocera assemblages from five European mountain lakes showed only a weak or no response to air temperature during the last ca. 200 years (Battarbee et al., 2002). Battarbee et al. (2002) assumed that the Cladocera composition of these lakes was not sensitive to the range of temperature variation of the last 200 years. They hypothesized that Cladocera did not show climaterelated changes, because the lakes selected in their study were not located near ecological boundaries or thresholds that were important for Cladocera.

The objective of this study was to assess the potential of Cladocera from lakes of the NiedereTauern (NT) area (Austrian Alps) for climate reconstruction. The lakes are located along an air temperature gradient; they are sensitive to climate change (Thompson et al., 2005). Instead of taking a single sample from the littoral and / or open water, we analyzed surface sediments from the deepest part of the lakes which integrate Cladocera over several years. This approach helped us avoiding bias introduced by the seasonal occurrence of Cladocera. Cladocera were related to the main underlying environmental gradients found among 29 abiotic variables using statistical methods. The significance of our findings with regard to Cladocera-based climate reconstruction is discussed.

\section{Study area}

We selected 45 lakes in the Central Alps (Niedere Tauern, Table 1) that stretch from the sub-alpine forested belt up to the mid-alpine zone (1,502-2,309 $\mathrm{m}$ asl). The altitudinal gradient reflects a major climate gradient with temperature decreasing with increasing altitude (Barry, 2001). Although the highest peaks rise above $2,800 \mathrm{~m}$ asl, there are no glaciers in the Niedere-Tauern. We particularly selected the region above $1,500 \mathrm{~m}$ asl, because lower mountain valleys tend to be affected by air-temperature inversions (Barry, 2001). The lakes were chosen to be as pristine as possible, while encompassing a wide spread of geographic settings, water chemistries, and basin morphologies. Their watersheds are located on predominantly crystalline bedrock with schists and metamorphic carbonates, which prevent them from being acidified. Table 2 lists summary statistics on physical, chemical, and morphometric characteristics.

\section{Materials and methods}

\section{Cladocera analysis}

Surface sediments (depth: $1 \mathrm{~cm}$, diameter: $6 \mathrm{~cm}$ ) were collected from the deepest areas of the 45 lakes 
Table 1 Geographic position of the studied lakes and Cladocera found

\begin{tabular}{|c|c|c|c|c|c|}
\hline Lake & No. & Longitude & Latitude & Altitude ( $\mathrm{m}$ asl) & Cladocera \\
\hline Ahornsee & 1 & $13^{\circ} 59^{\prime} 03^{\prime \prime} \mathrm{E}$ & $47^{\circ} 18^{\prime} 33^{\prime \prime} \mathrm{N}$ & 2,069 & Only littoral \\
\hline Angersee & 2 & $13^{\circ} 48^{\prime} 48^{\prime \prime} \mathrm{E}$ & $47^{\circ} 17^{\prime} 22^{\prime \prime} \mathrm{N}$ & 2,096 & None \\
\hline Eiskarsee & 3 & $13^{\circ} 43^{\prime} 52^{\prime \prime} \mathrm{E}$ & $47^{\circ} 17^{\prime} 00^{\prime \prime} \mathrm{N}$ & 1,940 & Only littoral \\
\hline Elendbergsee & 4 & $13^{\circ} 44^{\prime} 21^{\prime \prime} \mathrm{E}$ & $47^{\circ} 17^{\prime} 00^{\prime \prime} \mathrm{N}$ & 2,215 & None \\
\hline Grünsee & 5 & $13^{\circ} 59^{\prime} 03^{\prime \prime} \mathrm{E}$ & $47^{\circ} 17^{\prime} 14^{\prime \prime} \mathrm{N}$ & 1,984 & Only littoral \\
\hline Hinterkarsee & 6 & $13^{\circ} 54^{\prime} 23^{\prime \prime} \mathrm{E}$ & $47^{\circ} 15^{\prime} 06^{\prime \prime} \mathrm{N}$ & 2,074 & Only littoral \\
\hline Hohensee & 7 & $14^{\circ} 00^{\prime} 31^{\prime \prime} \mathrm{E}$ & $47^{\circ} 17^{\prime} 16^{\prime \prime} \mathrm{N}$ & 1,541 & Littoral and planktonic \\
\hline Hüttensee & 8 & $13^{\circ} 49^{\prime} 02^{\prime \prime} \mathrm{E}$ & $47^{\circ} 21^{\prime} 30^{\prime \prime} \mathrm{N}$ & 1,502 & Only littoral \\
\hline Hüttkarsee & 9 & $13^{\circ} 54^{\prime} 18^{\prime \prime} \mathrm{E}$ & $47^{\circ} 15^{\prime} 52^{\prime \prime} \mathrm{N}$ & 2,137 & Only littoral \\
\hline Kaltenbachsee & 10 & $13^{\circ} 47^{\prime} 12^{\prime \prime} \mathrm{E}$ & $47^{\circ} 20^{\prime} 36^{\prime \prime} \mathrm{N}$ & 2,214 & None \\
\hline Kapuzinersee & 11 & $13^{\circ} 48^{\prime} 30^{\prime \prime} \mathrm{E}$ & $47^{\circ} 17^{\prime} 46^{\prime \prime} \mathrm{N}$ & 2,147 & Only littoral \\
\hline Knappenkarsee & 12 & $13^{\circ} 40^{\prime} 29^{\prime \prime} \mathrm{E}$ & $47^{\circ} 16^{\prime} 10^{\prime \prime} \mathrm{N}$ & 2,257 & Only littoral \\
\hline Landauersee & 13 & $13^{\circ} 40^{\prime} 00^{\prime \prime} \mathrm{E}$ & $47^{\circ} 18^{\prime} 15^{\prime \prime} \mathrm{N}$ & 1,653 & Littoral and planktonic \\
\hline Lungauer Klaffersee & 14 & $13^{\circ} 47^{\prime} 55^{\prime \prime} \mathrm{E}$ & $47^{\circ} 17^{\prime} 00^{\prime \prime} \mathrm{N}$ & 2,196 & None \\
\hline Mitterkarsee & 15 & $13^{\circ} 55^{\prime} 00^{\prime \prime} \mathrm{E}$ & $47^{\circ} 14^{\prime} 36^{\prime \prime} \mathrm{N}$ & 2,150 & Littoral and planktonic \\
\hline Mittlerer Kaltenbachsee & 16 & $14^{\circ} 03^{\prime} 51^{\prime \prime} \mathrm{E}$ & $47^{\circ} 16^{\prime} 55^{\prime \prime} \mathrm{N}$ & 1,912 & Littoral and planktonic \\
\hline Mittlerer Landschitzsee & 17 & $13^{\circ} 50^{\prime} 53^{\prime \prime} \mathrm{E}$ & $47^{\circ} 15^{\prime} 00^{\prime \prime} \mathrm{N}$ & 1,940 & Only littoral \\
\hline Moaralmsee & 18 & $13^{\circ} 47^{\prime} 32^{\prime \prime} \mathrm{E}$ & $47^{\circ} 21^{\prime} 28^{\prime \prime} \mathrm{N}$ & 1,825 & Littoral and planktonic \\
\hline Oberer Giglachsee & 19 & $13^{\circ} 38^{\prime} 36^{\prime \prime} \mathrm{E}$ & $47^{\circ} 16^{\prime} 46^{\prime \prime} \mathrm{N}$ & 1,930 & Littoral and planktonic \\
\hline Oberer Klaffersee & 20 & $13^{\circ} 48^{\prime} 02^{\prime \prime} \mathrm{E}$ & $47^{\circ} 17^{\prime} 34^{\prime \prime} \mathrm{N}$ & 2,309 & Only littoral \\
\hline Oberer Landschitzsee & 21 & $13^{\circ} 51^{\prime} 33^{\prime \prime} \mathrm{E}$ & $47^{\circ} 14^{\prime} 49^{\prime \prime} \mathrm{N}$ & 2,067 & Littoral and planktonic \\
\hline Oberer Landwiersee & 22 & $13^{\circ} 43^{\prime} 13^{\prime \prime} \mathrm{E}$ & $47^{\circ} 15^{\prime} 55^{\prime \prime} \mathrm{N}$ & 2,047 & Only littoral \\
\hline Oberer Schönalmsee & 23 & $13^{\circ} 36^{\prime} 04^{\prime \prime} \mathrm{E}$ & $47^{\circ} 13^{\prime} 30^{\prime \prime} \mathrm{N}$ & 2,111 & Littoral and planktonic \\
\hline Oberer Sonntagkarsee & 24 & $13^{\circ} 49^{\prime} 53^{\prime \prime} \mathrm{E}$ & $47^{\circ} 18^{\prime} 05^{\prime \prime} \mathrm{N}$ & 2,063 & Only littoral \\
\hline Oberer Zwieflersee & 25 & $14^{\circ} 02^{\prime} 39^{\prime \prime} \mathrm{E}$ & $47^{\circ} 15^{\prime} 00^{\prime \prime} \mathrm{N}$ & 1,925 & Littoral and planktonic \\
\hline Oberhüttensee & 26 & $13^{\circ} 36^{\prime} 10^{\prime \prime} \mathrm{E}$ & $47^{\circ} 16^{\prime} 43^{\prime \prime} \mathrm{N}$ & 1,863 & Littoral and planktonic \\
\hline Obersee & 27 & $13^{\circ} 49^{\prime} 06^{\prime \prime} \mathrm{E}$ & $47^{\circ} 21^{\prime} 04^{\prime \prime} \mathrm{N}$ & 1,672 & Littoral and planktonic \\
\hline Pfannsee & 28 & $13^{\circ} 48^{\prime} 25^{\prime \prime} \mathrm{E}$ & $47^{\circ} 21^{\prime} 00^{\prime \prime} \mathrm{N}$ & 1,967 & Littoral and planktonic \\
\hline Rantensee & 29 & $13^{\circ} 53^{\prime} 47^{\prime \prime} \mathrm{E}$ & $47^{\circ} 15^{\prime} 00^{\prime \prime} \mathrm{N}$ & 1,880 & None \\
\hline Rauhenbergsee & 30 & $13^{\circ} 47^{\prime} 21^{\prime \prime} \mathrm{E}$ & $47^{\circ} 17^{\prime} 41^{\prime \prime} \mathrm{N}$ & 2,263 & Only littoral \\
\hline Schwarzensee & 31 & $13^{\circ} 59^{\prime} 21^{\prime \prime} \mathrm{E}$ & $47^{\circ} 17^{\prime} 26^{\prime \prime} \mathrm{N}$ & 1,916 & Only littoral \\
\hline Tiefenbachsee & 32 & $13^{\circ} 36^{\prime} 21^{\prime \prime} \mathrm{E}$ & $47^{\circ} 14^{\prime} 25^{\prime \prime} \mathrm{N}$ & 1,844 & Littoral and planktonic \\
\hline Twenger Almsee & 33 & $13^{\circ} 36^{\prime} 05^{\prime \prime} \mathrm{E}$ & $47^{\circ} 13^{\prime} 13^{\prime \prime} \mathrm{N}$ & 2,118 & Littoral and planktonic \\
\hline Unterer Giglachsee & 34 & $13^{\circ} 39^{\prime} 00^{\prime \prime} \mathrm{E}$ & $47^{\circ} 17^{\prime} 00^{\prime \prime} \mathrm{N}$ & 1,922 & Littoral and planktonic \\
\hline Unterer Kaltenbachsee & 35 & $14^{\circ} 04^{\prime} 11^{\prime \prime} \mathrm{E}$ & $47^{\circ} 16^{\prime} 41^{\prime \prime} \mathrm{N}$ & 1,749 & Littoral and planktonic \\
\hline Unterer Klaffersee & 36 & $13^{\circ} 47^{\prime} 36^{\prime \prime} \mathrm{E}$ & $47^{\circ} 18^{\prime} 00^{\prime \prime} \mathrm{N}$ & 2,103 & Only littoral \\
\hline Unterer Klaftersee & 37 & $13^{\circ} 59^{\prime} 46^{\prime \prime} \mathrm{E}$ & $47^{\circ} 19^{\prime} 00^{\prime \prime} \mathrm{N}$ & 1,883 & None \\
\hline Unterer Landschitzsee & 38 & $13^{\circ} 50^{\prime} 21^{\prime \prime} \mathrm{E}$ & $47^{\circ} 15^{\prime} 18^{\prime \prime} \mathrm{N}$ & 1,782 & Littoral and planktonic \\
\hline Unterer Landwiersee & 39 & $13^{\circ} 43^{\prime} 29^{\prime \prime} \mathrm{E}$ & $47^{\circ} 16^{\prime} 05^{\prime \prime} \mathrm{N}$ & 1,978 & Only littoral \\
\hline Unterer Sonntagkarsee & 40 & $13^{\circ} 49^{\prime} 46^{\prime \prime} \mathrm{E}$ & $47^{\circ} 18^{\prime} 24^{\prime \prime} \mathrm{N}$ & 1,962 & Only littoral \\
\hline Unterer Wirpitschsee & 41 & $13^{\circ} 36^{\prime} 38^{\prime \prime} \mathrm{E}$ & $47^{\circ} 14^{\prime} 06^{\prime \prime} \mathrm{N}$ & 1,700 & Littoral and planktonic \\
\hline Unterer Zwieflersee & 42 & $14^{\circ} 03^{\prime} 12^{\prime \prime} \mathrm{E}$ & $47^{\circ} 14^{\prime} 54^{\prime \prime} \mathrm{N}$ & 1,808 & Littoral and planktonic \\
\hline Weißensee & 43 & $13^{\circ} 58^{\prime} 44^{\prime \prime} \mathrm{E}$ & $47^{\circ} 18^{\prime} 47^{\prime \prime} \mathrm{N}$ & 2,226 & Only littoral \\
\hline Wildlochsee & 44 & $13^{\circ} 49^{\prime} 00^{\prime \prime} \mathrm{E}$ & $47^{\circ} 20^{\prime} 00^{\prime \prime} \mathrm{N}$ & 2,108 & None \\
\hline Zwerfenbergsee & 45 & $13^{\circ} 48^{\prime} 38^{\prime \prime} \mathrm{E}$ & $47^{\circ} 17^{\prime} 07^{\prime \prime} \mathrm{N}$ & 2,025 & None \\
\hline
\end{tabular}


Table 2 Summary statistics of 29 environmental variables from 45 lakes

\begin{tabular}{|c|c|c|c|c|c|c|c|c|}
\hline \multirow[t]{2}{*}{ Variable } & \multirow[t]{2}{*}{ Abbrev. } & \multirow[t]{2}{*}{ Units } & \multicolumn{3}{|c|}{ Summary statistics } & \multicolumn{3}{|c|}{ Principal components } \\
\hline & & & Min & Median & Max & Axis 1 & Axis 2 & Axis 3 \\
\hline \multicolumn{9}{|l|}{ Climate-related variables } \\
\hline Mean monthly June water temperature & $T_{\text {Jun }}$ & Celsius & 0.0 & 4.7 & 9.1 & -0.85 & -0.30 & -0.25 \\
\hline Mean monthly July water temperature & $T_{\mathrm{Jul}}$ & Celsius & 1.7 & 9.0 & 12.4 & -0.90 & 0.07 & -0.19 \\
\hline Mean monthly August water temperature & $T_{\text {Aug }}$ & Celsius & 6.1 & 10.7 & 13.7 & -0.69 & 0.47 & -0.19 \\
\hline Mean monthly September water temperature & $T_{\text {Sep }}$ & Celsius & 4.7 & 7.6 & 9.5 & -0.76 & 0.38 & -0.28 \\
\hline Mean monthly October water temperature & $T_{\text {Oct }}$ & Celsius & 1.5 & 4.8 & 6.2 & $-\mathbf{0 . 8 3}$ & 0.17 & -0.28 \\
\hline Date of ice-break & Break & Julian days & 118 & 146 & 198 & 0.73 & 0.41 & 0.29 \\
\hline Date of freeze-up & Freeze & Julian days & 286 & 305 & 326 & -0.66 & 0.17 & -0.28 \\
\hline Length ice cover & Ice & Julian days & 163 & 205 & 277 & 0.80 & 0.27 & 0.32 \\
\hline 'Date of spring mixing' & $S_{\text {mix }}$ & Julian days & 133 & 158 & 264 & 0.76 & 0.18 & 0.35 \\
\hline 'Date of autumn mixing' & $A_{\text {mix }}$ & Julian days & 262 & 294 & 303 & -0.79 & 0.07 & -0.16 \\
\hline Altitude & Alt & $\mathrm{m}$ asl & 1502 & 1978 & 2309 & 0.78 & 0.33 & 0.23 \\
\hline \multicolumn{9}{|l|}{ Chemical variables } \\
\hline $\mathrm{pH}$ & $\mathrm{pH}$ & & 6.9 & 7.2 & 8.2 & -0.48 & 0.30 & 0.75 \\
\hline Alkalinity & Alk & $\mu$ eq $1^{-1}$ & 22.0 & 131.5 & 1364.0 & -0.59 & 0.04 & 0.75 \\
\hline Conductivity & Cond & $\mu \mathrm{S}_{25} \mathrm{~cm}^{-1}$ & 11.9 & 25.9 & 137.3 & -0.59 & -0.08 & 0.79 \\
\hline Calcium & $\mathrm{Ca}$ & $\mu$ eq $1^{-1}$ & 70.1 & 198.7 & 1058.8 & -0.53 & -0.11 & 0.80 \\
\hline Magnesium & $\mathrm{Mg}$ & $\mu$ eq $1^{-1}$ & 10.5 & 21.6 & 303.8 & -0.69 & 0.18 & 0.61 \\
\hline Sodium & $\mathrm{Na}$ & $\mu$ eq $1^{-1}$ & 9.7 & 17.5 & 32.4 & -0.36 & -0.69 & 0.19 \\
\hline Potassium & $\mathrm{K}$ & $\mu$ eq $1^{-1}$ & 3.4 & 8.2 & 21.0 & 0.18 & -0.58 & -0.25 \\
\hline Chloride & $\mathrm{Cl}$ & $\mu$ eq $1^{-1}$ & 1.7 & 2.8 & 4.8 & -0.57 & -0.34 & 0.04 \\
\hline Sulfate & $\mathrm{SO}_{4}$ & $\mu$ eq $1^{-1}$ & 28.7 & 71.2 & 295.8 & -0.14 & -0.48 & 0.56 \\
\hline Total inorganic nitrogen & TIN & $\mu$ eq $1^{-1}$ & 0.0 & 9.0 & 18.1 & 0.22 & -0.74 & -0.08 \\
\hline Total dissolved nitrogen & $\mathrm{DN}$ & $\mu \mathrm{g} 1^{-1}$ & 82 & 234 & 397 & 0.23 & -0.72 & -0.03 \\
\hline Total phosphorus & $\mathrm{TP}$ & $\mu \mathrm{g} 1^{-1}$ & 1.0 & 3.2 & 7.8 & -0.16 & 0.61 & -0.08 \\
\hline Total particulate phosphorus & $\mathrm{PP}$ & $\mu \mathrm{g} 1^{-1}$ & 0.1 & 1.5 & 6.4 & 0.01 & 0.44 & -0.19 \\
\hline Total dissolved phosphorus & DP & $\mu \mathrm{g} 1^{-1}$ & 0.2 & 1.4 & 3.3 & -0.52 & 0.29 & 0.20 \\
\hline Total dissolved reactive silica & DRSi & $\mu \mathrm{g} 1^{-1}$ & 279 & 762 & 1,685 & -0.20 & -0.85 & -0.11 \\
\hline Dissolved organic carbon & DOC & $\mathrm{mg}^{-1}$ & 0.41 & 0.60 & 2.06 & -0.39 & 0.47 & -0.46 \\
\hline \multicolumn{9}{|l|}{ Lake morphometry } \\
\hline Maximum lake depth & $z_{\max }$ & $\mathrm{m}$ & 5.7 & 13.4 & 43.6 & 0.08 & 0.36 & -0.01 \\
\hline Relative lake depth ${ }^{\mathrm{a}}$ & $z_{\text {rel }}$ & $\mathrm{m}$ & 3.0 & 6.1 & 17.9 & 0.40 & 0.37 & 0.15 \\
\hline $\begin{array}{l}\text { Amount of variance in the environmental data } \\
\text { explained by Principal Components axes: }\end{array}$ & & & & & & $33 \%$ & $18 \%$ & $15 \%$ \\
\hline
\end{tabular}

Correlation coefficients indicate the measure of fit with significant Principal Component (PC) axes 1-3 (broken stick model). Scores $>0.7$ are presented in boldface. PC-axes 1-3 represent three major environmental gradients related to climate, nutrients, and alkalinity. Pfannsee was excluded from PC analysis because it lacked chemical measurements. PC-sample scores are shown in Fig. 1

a Lake area $\left(\mathrm{m}^{2}\right) /$ maximum lake depth (m) 
during summer 1999 using a modified Kajak gravity corer. Samples (5 g wet sediment) were cleaned following Frey (1986): (i) removal of carbonates using $\mathrm{HCl}$ (10\%); (ii) heating and stirring in $\mathrm{KOH}$ (10\%) for $30 \mathrm{~min}$ to remove organic matter; (iii) washing and sieving $(40 \mu \mathrm{m})$ of the residue, which was then diluted with distilled water (up to $10 \mathrm{ml}$ ), and mounted onto light-microscope slides $(0.1 \mathrm{ml}$ per slide). A minimum of 200 individuals per sample were counted (3-10 slides per sample). Their remains (headshields, shells, postabdomens, and postabdominal claws, excluding ephippia) were analyzed at $100 \times$ and 200× magnification using an OLYMPUS light microscope. The arrangement of fragmented remains into species followed Frey (1986). Cladocera taxonomy followed Goulden \& Frey (1963), Frey (1964, 1991) and Flössner (1972, 2000).

\section{Environmental variables}

Kamenik et al. (2001) and Schmidt et al. (2004a, b) set out the details of the training set measurements. The survey involved water temperature, lake morphology, and water chemistry (Table 2) measured at the lake-centers (2 m water depth) on 18th/19th October 1999, i.e., around the time of autumn mixing (8th October-10th November 1999), when chemical characteristics tend to be similar throughout the water column. We avoided measuring water chemistry around the time of spring mixing, because chemical features can be highly variable during this period (Catalan et al., 2002). Epilimnion water-temperatures were measured at two-hour intervals using one or two 8-bit MINILOG-TR thermistors (Vemco Ltd.) per lake. Thermistors were exposed off the shore from summer 1998 to summer 1999. Temperature readings were averaged for the months June-October $\left(T_{\mathrm{Jun}^{-}}-\right.$ $\left.T_{\text {Oct }}\right)$. Schmidt et al. (2004a, b) estimated freeze and breakup dates for each lake by visual examination of individual temperature logs. The reference dates 'date of spring mixing' $\left(S_{\text {mix }}\right)$ and 'date of autumn mixing' $\left(A_{\text {mix }}\right)$ were defined as the first day after thawing or summer stratification when the mean daily water temperature was $4^{\circ} \mathrm{C}$ (Schmidt et al., 2004b).

Numerical methods

The Cladocera counts were converted to presence/ absence or percentages. Cladocera data were thus independent from changes in sediment characteristics. Percentages were square-root transformed to stabilize their variance. We did not perform 'downweighting of rare species' (ter Braak \& Šmilauer, 2002), because maximum abundance was always $\geq 3 \%$, and because downweighting would have resulted in a weighting of $50 \%$ of the species. Cladocera assemblages were compared using a dissimilarity index (Chord distance), and grouped according to Non-Metric Multidimensional Scaling (MDS) and Hierarchical Agglomerative Clustering (UPGMA) (Legendre \& Legendre, 1998). Cladocera that characterized specific groups of lakes were identified using the indicator-value approach (Dufrêne \& Legendre, 1997). The significance of indicator values was assessed by randomization (999 permutations).

Main patterns in the environmental variables and the corresponding lakes were elucidated by Principal Components (PC) analysis (Table 2, Fig. 1) after data were centered and standardized (Legendre \& Legendre, 1998). The significance of PC-axes was assessed by the broken stick model (Jackson, 1993). Isolines of environmental variables were projected onto a PCplot using generalized additive models with PC-axes 1 and 2 as predictors, a normal error structure and an identity link function (Venables \& Ripley, 2002; Lepš \& Šmilauer, 2003). All environmental variables, except pH (i.e., $-\log _{10}\left[\mathrm{H}^{+}\right]$), were $\log _{10}$ transformed to avoid skewed distributions. Linear relationships between $\left[\mathrm{H}^{+}\right]$and other ions were thus retained (Stumm \& Morgan, 1996).

We used a Classification Tree and Canonical Variates Analysis (also known as Linear Discriminant Analysis) to analyze relationships between the presence/absence of Cladocera and environmental variables (Venables \& Ripley, 2002), and Canonical Correspondence Analysis to study potential effects of these variables on the Cladocera assemblages (Legendre \& Legendre, 1998). A preliminary Detrended Correspondence Analyses (DCA, detrending by segments) on the Cladocera assemblages resulted in a gradient length of 2.4 standard deviation units, suggesting unimodal species responses (ter Braak, 1987; Birks, 1995). DCA and CCA helped identifying outlying samples (ter Braak, 1987). A series of Detrended Canonical Correspondence Analyses (DCCA) constrained to a single environmental variable at a time were run to check the influence of each 


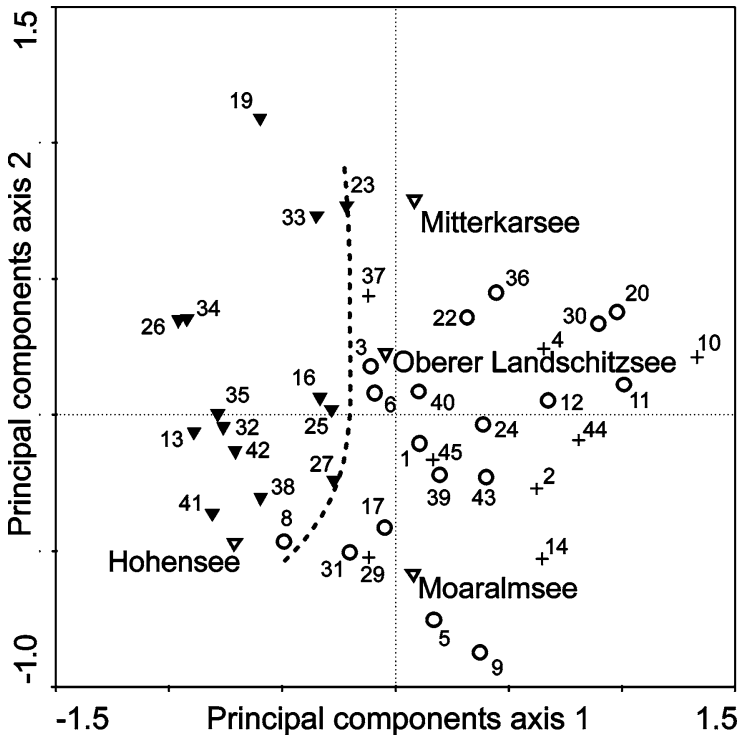

Fig. 1 Surface-sediment sample-scores from a PCA based on 44 lakes (Table 1) and 29 abiotic variables (Table 2). The samples are grouped in lakes (i) that lack Cladocera (crosses), (ii) that have only littoral Cladocera (circles), and (iii) that have littoral and planktonic Cladocera (triangles). The transition from lakes with planktonic Cladocera to lakes without planktonic Cladocera is related to a 'date of autumn mixing' of 297 Julian days (dashed line, fitted by GAM, $P<0.001$ ). Black and white fillings reflect results from numerical clustering, and agree with the occurrence of Cladocera, except for the four-labeled lakes (for numbering see Table 1). Significant PC-axis 3 did not separate lakes with Cladocera from lakes without Cladocera. Pfannsee was excluded because it lacked chemical measurements

variable on the Cladocera assemblages (marginal effects). DCCA helped assessing the gradient length of the environmental variable in standard deviation (SD) units (turnover units of beta-diversity). Using DCCA, we determined the strength of each variable by its ability to maximize the dispersion of the taxon scores (ter Braak \& Juggins, 1993), expressed as a ratio of the eigenvalue of the constrained ordination axis to the eigenvalue of the first unconstrained ordination axis $\left(\lambda_{1} / \lambda_{2}\right)$.

We used PC-axis 1 sample-scores (see Table 2) as an index for climate; PC-axis 1 was highest correlated with climate-related variables (compare with Thompson et al., 2005). Furthermore, we used PCaxis 2 and 3 sample-scores as indices for nutrients (e.g., from pastures) and alkalinity supply (e.g., from weathering of bedrock minerals); they were highly correlated with nitrogen fractions and alkalinity, respectively (compare with Kamenik et al., 2001). Because PC axes are not correlated (e.g., Legendre \& Legendre, 1998), the three indices were independent from each other. The significance of explanatory variables, of individual CCA and DCCA axes, and of the tree-based statistical classification model was tested using 999 unrestricted permutations (ter Braak \& Šmilauer, 2002). To eliminate spurious marginal effects, we adjusted their probability values for multiple testing $\left(P_{\mathrm{adj}}<0.05\right)$ using the conservative Bonferroni correction (Wright, 1992).

Finally, we used the optimal sum-of-squares partitioning method (Birks \& Gordon, 1985), as implemented in the program ZONE (Lotter \& Juggins, 1991), and the broken-stick model (Bennett, 1996) to detect significant changes among Cladocera assemblages along environmental gradients of interest.

Bivariate statistical analysis followed Venables \& Ripley (2002) and Venables \& Smith (2002) using the $\mathrm{R}$ language. Ordinations (PCA, CVA, DCA, CCA, DCCA) were calculated using the program CANOCO 4.5 (ter Braak \& Šmilauer, 2002). For MDS, cluster analysis, and the tree-based statistical classification model we used the R-libraries CLUSTER, MASS, RPART, and RPART.PERMUTATION (Venables \& Ripley, 2002; Cummings et al., 2004). Indicator values were calculated using the program IndVal (Dufrêne \& Legendre, 1997).

\section{Results}

General characteristics

We found 14 different Cladocera of the families Bosminidae, Daphniidae, and Chydoridae. Shells and head shields were the most abundant remains. Unknown remains were discovered in Unterer Wirpitschsee and nearby Tiefenbachsee. In eight lakes no Cladocera could be found (Figs. 1, 2). In lakes with Cladocera, we found one (Alona affinis in Weissensee) to nine (Hohensee) species. Planktonic Cladocera (Daphnia longispina-group, D. pulex-group, Bosmina (Eubosmina) type, and Bosmina longirostris) were found in 19 lakes (Figs. 1, 2). The littoral Cladocera Alona affinis and Acroperus harpae had the highest number of occurrence (we found A. affinis 


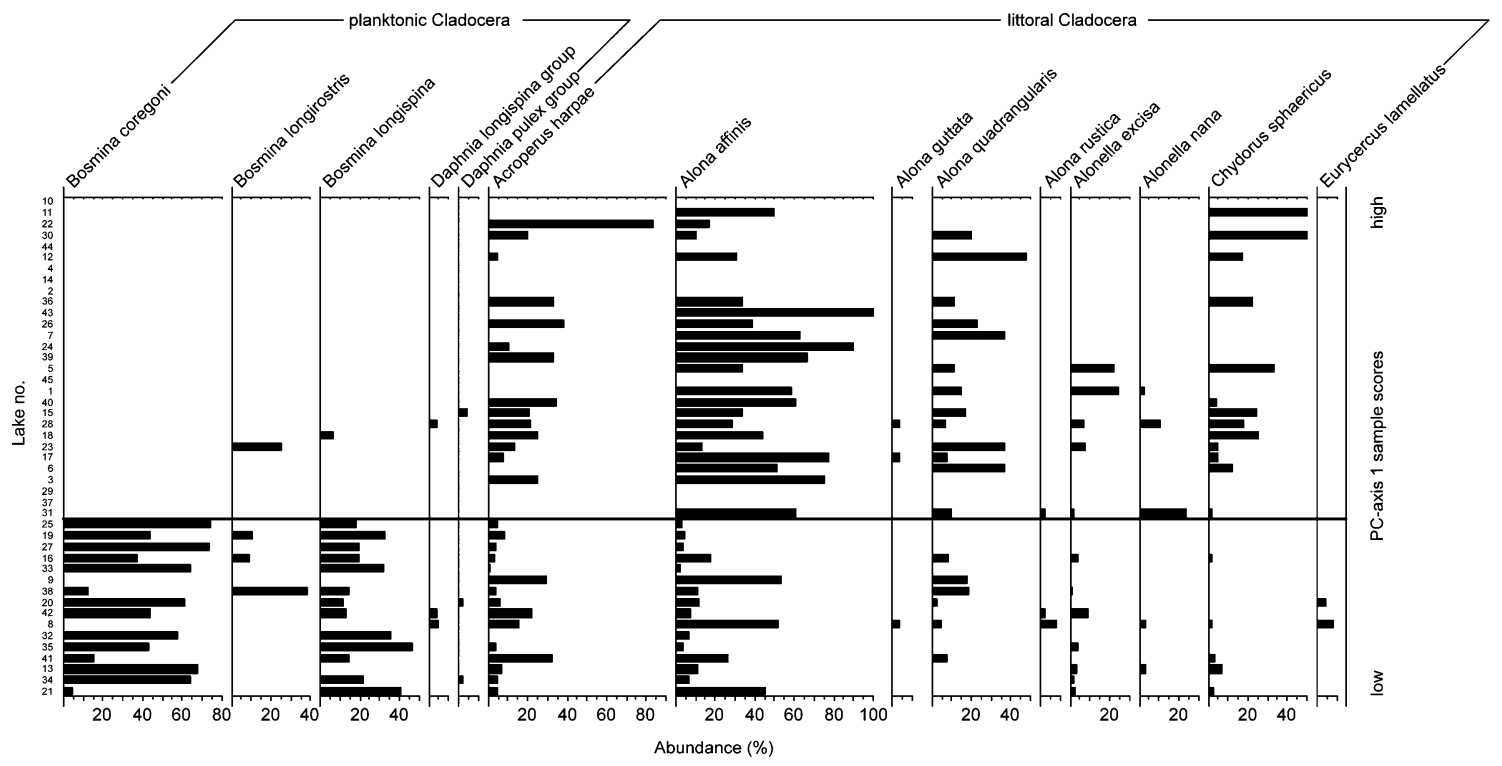

Fig. 2 Abundance of Cladocera ordered along PC-axis 1 sample-scores; the horizontal line indicates a significant change in the Cladocera assemblages according to optimal partitioning (based on Cladocera percentages) and the broken stick model, and corresponds to e.g., a 'date of autumn mixing' of 297 Julian days (Fig. 1). Low/high sample scores denote

in 37 and A. harpae in 29 lakes), followed by Alona quadrangularis and Chydorus sphaericus (both found in 19 lakes). The total number of Cladocera fluctuated around 200 per gram wet sediment (median value). The maximum concentration of Cladocera was 1,850 per gram wet sediment in Obersee.

Detrended Correspondence Analysis (DCA) did not indicate unusual Cladocera assemblages. MDS, cluster analysis, and the indicator value approach revealed that there were two different groups of Cladocera assemblages that were characterized either by planktonic Cladocera (Bosmina coregoni, Bosmina longirostris) or by littoral Cladocera (Alona affinis, Alona quadrangularis, Chydorus sphaericus). The former group included all lakes with planktonic Cladocera except for Hohensee, Mitterkarsee, Moaralmsee, Oberer Landschitzsee, and Pfannsee (Fig. 1). These lakes had either a high abundance of Alona quadrangularis (Oberer Landschitzsee) or low abundances $(<7 \%)$ of planktonic Cladocera (Fig. 2).

A classification tree suggested that at mean August water temperature $\left(T_{\text {Aug }}\right)<8.9^{\circ} \mathrm{C}$ no Cladocera could be found (misclassifying Grünsee, Elendbergsee, Rantensee, Unterer Klaftersee, and Zwerfenbergsee); the same classification tree suggested that at mean warm/cold lakes, respectively. Pfannsee (no. 28), which lacked chemical measurements, was inserted according to (i) a PCA on climate-related variables and lake morphology (Table 2) and (ii) similarity among Cladocera assemblages (cluster analysis)

October air temperature $\left(T_{\text {Oct }}\right)>5.1^{\circ} \mathrm{C}$ there were both littoral and planktonic Cladocera in the surface sediments (misclassifying Hüttensee, Mitterkarsee, Moaralmsee, and Pfannsee). Canonical Variates Analysis (CVA) revealed that Zwerfenbergsee could not be classified correctly even when considering all 29 environmental variables. $T_{\text {Oct }}$ had highest correlation with 'date of autumn mixing' (Kendall's $\tau=0.82$ ). The 'date of autumn mixing' isoline of 297 Julian days separated lakes with planktonic Cladocera from lakes without (overall significance of the underlying GAM model according to $F$-statistics: $P<0.001)$. Hüttensee, Mitterkarsee, Moaralmsee, and Oberer Landschitzsee were misclassified in the PC-plot (Fig. 1). Pfannsee was excluded from PCA and CVA because it lacked chemical measurements.

Correlations of Cladocera assemblages with environmental variables

Ten environmental variables and PC-axis 1 , which was highly correlated with climate-related variables, had significant marginal effects (taking into account multiple testing). They explained $9.1-15.1 \%$ of variation among the Cladocera assemblages 
Table 3 DCCA results, based on Cladocera percentages, listing environmental variables, and PC-sample scores (Table 2), which singly explained a significant amount of variation in the Cladocera assemblages found in 37 lakes (marginal effects)

\begin{tabular}{lccc}
\hline & Percentage of variation explained & $\lambda_{1} / \lambda_{2}$ & Gradient length \\
\hline 'Date of autumn mixing' & 15.1 & 0.88 & 1.8 \\
PC-axis 1 sample-scores & 15.0 & 0.85 & 1.8 \\
Magnesium & 14.7 & 0.87 & 1.7 \\
Mean monthly October water temperature & 14.4 & 0.84 & 2.1 \\
Mean monthly September water temperature & 12.1 & 0.61 & 1.7 \\
Alkalinity & 10.8 & 0.62 & 1.7 \\
Total phosphorus & 10.8 & 0.67 & 1.7 \\
Mean monthly July water temperature & 10.7 & 0.47 & 1.6 \\
pH & 10.6 & 0.58 & 1.6 \\
Total dissolved phosphorus & 10.3 & 0.51 & 1.8 \\
Conductivity & 9.6 & 0.52 & 1.5
\end{tabular}

PC-sample scores were used as indices for climate (axis 1), nutrients (axis 2), and alkalinity supply (axis 3 ). $\lambda_{1} / \lambda_{2}$ show the strength of each variable by its ability to maximize the dispersion of the taxon scores. High values indicate strong secondary gradients. Gradient lengths, given in turnover units of beta-diversity, show the amount of compositional change along the variables

(Table 3). 'Date of autumn mixing' explained most of the variation. According to DCCA, the amount of compositional change along these variables ranged from 1.5 to 2.1 standard deviation (SD) units (turnover units of beta-diversity). DCCA indicated strong secondary gradients $\left(\lambda_{1} / \lambda_{2}<0.9\right)$. Optimal partitioning and the broken-stick model revealed that along PC-axis 1 there was a significant change in the Cladocera assemblages. This change mainly denoted a shift from assemblages characterized by planktonic Cladocera to assemblages characterized by littoral Cladocera (Fig. 2).

CCA based on the three PC axes, which summarized the main underlying gradients in the environmental variables (Table 2), resulted in two significant canonical correspondence axes, which explained $24.8 \%$ of the variation in the Cladocera assemblages. The three PC-axes sample-scores had significant conditional effects (i.e., they significantly explained additional variation in the Cladocera assemblages after other PC axes had been considered). PC-axis 1 sample-scores were highest correlated with canonical correspondence axis 1; PC-axis 3 sample-scores were highest correlated with canonical correspondence axis 2 (Table 4).

Canonical correspondence axis 1 separated lakes with planktonic Cladocera from lakes without planktonic Cladocera. According to their Indicator Values, the three Bosminidae characterized warm/nutrient- rich lakes; in turn, Alona affinis and Chydorus sphaericus characterized cold/nutrient-poor lakes. The first unconstrained axis explained a high amount of variation in the Cladocera assemblages (Table 4). Hohensee, which is a shallow lake $\left(z_{\text {rel }}=3.0 \mathrm{~m}\right)$ at an altitude of $1,541 \mathrm{~m}$ asl, was an outlier on this first unconstrained axis (sample-score $>2.5 \times$ higher than the interquartile range of all sample scores).

\section{Discussion}

\section{General characteristics}

The main compositional change in Cladocera assemblages from Swiss lakes located along an altitude gradient ranging from $334 \mathrm{~m}$ asl to $2,339 \mathrm{~m}$ asl occurred between 1,000 $\mathrm{m}$ asl and 1,500 m asl (Lotter et al., 1997). The NT-Cladocera assemblages were all sampled from lakes located above 1,500 m asl. They were mainly characterized by cold-tolerant planktonic (Bosminidae, Daphniidae) and littoral (Chydoridae) Cladocera.

The most frequent Cladocera from the NT-sediments were Chydoridae that were classified as either 'arctic' (Acroperus harpae, Chydorus sphaericus), 'sub-arctic' (Alona affinis) or 'north-temperate' (Alona quadrangularis), according to their occurrence at high-latitude sites (Harmsworth, 1968). 
Table 4 CCA (summary) based on percentages of 14 different Cladocera, 35 samples and sample-scores derived from a PCA on environmental variables (Table 2) which were used as indices for climate (axis 1), nutrients (axis 2), and alkalinity supply (axis 3)

\begin{tabular}{|c|c|c|c|c|}
\hline Canonical correspondence axes: & 1 & 2 & 3 & First unconstrained axis \\
\hline Eigenvalues & 0.31 & 0.12 & 0.04 & 0.30 \\
\hline Species environment correlations & 0.79 & 0.74 & 0.62 & 0.00 \\
\hline \multicolumn{5}{|l|}{ Cumulative percentage of variance } \\
\hline of species data & 17.8 & 24.8 & 27.4 & 44.6 \\
\hline of species-environment relationship & 65.1 & 90.7 & 100.0 & 0.00 \\
\hline Significance of axis (probability) & 0.001 & 0.019 & 0.706 & Not available \\
\hline \multicolumn{5}{|c|}{ Inter set correlations of environmental variables with axes } \\
\hline PC-axis 1 sample-scores & -0.69 & $\mathbf{0 . 3 2}$ & -0.14 & Not available \\
\hline PC-axis 2 sample-scores & 0.31 & 0.39 & -0.47 & Not available \\
\hline PC-axis 3 sample-scores & 0.25 & 0.57 & 0.34 & Not available \\
\hline Sum of all eigenvalues & & & & 1.72 \\
\hline Sum of all canonical eigenvalues & & & & 0.47 \\
\hline
\end{tabular}

Inter-set correlations of variables with significant canonical coefficients are presented in boldface (approximate $t$-value $>2.1$ )

During the Late-Glacial and earliest Post-Glacial, 'arctic and sub-arctic' Cladocera were often found to be pioneer taxa, i.e., early immigrants after ice withdrawal (e.g., Szeroczyńska, 1998a; Duigan \& Birks, 2000; Hofmann, 2000, 2001). The high number of occurrences of these Cladocera in the NT-lakes suggests that they should, however, not be regarded as cold stenothermal but as cold tolerant (Meijering, 1983). Alona affinis and Chydorus sphaericus, for example, are known to occur over a wide range of environmental conditions (e.g., Duigan \& Kovach, 1991; Duigan, 1992; Korhola, 1999).

Planktonic Cladocera were dominated by Bosminidae (Bosmina coregoni and B. longispina), which occurred in 'warm' and/or 'nutrient-rich' NT-lakes. Bosminidae were absent in oligotrophic mountain lakes in the Tatra Mountains (Szeroczyńska, 1984). Lotter et al. (1997) and Hofmann (2003) showed that Bosminidae played a minor role in the plankton of Swiss lakes above 1,800 m asl. Percentages of Bosmina sp. were shown to increase during climate amelioration or nutrient input (Harmsworth, 1968; Duigan \& Birks, 2000; Szeroczyńska, 2002; Gąsiorowski \& Szeroczyńska, 2004). However, like the previously mentioned Chydoridae, Bosmina coregoni, B. longirostris, and $B$. longispina are known to occur over a wide range of environmental conditions (Frey, 1988; Korhola, 1999; Gąsiorowski \& Szeroczyńska, 2004).

It is difficult to speculate upon the reasons for the absence of Cladocera in eight of the lakes. A classification tree suggested that water temperature was a driving force. Misclassifications revealed, however, that the absence of Cladocera is governed by a complex interplay of environmental factors. Unmeasured variables, such as poor preservation, oxygen concentration, water-transparency, damage by ultraviolet radiation, competition, grazing, food availability and predation, may strongly influence the Cladocera distribution (e.g., Hofmann, 1987; Whiteside \& Swindoll, 1988; Szeroczyńska, 1998b; Korhola, 1999; Williamson et al., 2001; Jeppesen et al., 2003).

Correlations of Cladocera assemblages with environmental variables

Direct gradient analysis (CCA, DCCA) stressed the importance of climate-related environmental variables for the Cladocera assemblages of the NT-lakes; however, instead of a gradual change along the climate gradient, we found a climate threshold at which we discovered a significant change in assemblage composition (Figs. 1, 2).

The strong climate-related change in Cladocera assemblages can be the result of both direct and indirect temperature effects (Lotter et al., 1997; Korhola, 1999). Temperature determines, for example, the inter-moult duration, which is intimately linked to the growth of Cladocera (Bottrell, 1975). Hofmann (2000) noted that the distribution of 
Cladocera did not always coincide with their thermal classification. Hofmann (2003) suggested that changes in the chydorid fauna in the Swiss-mountain Lake Sägistalsee $(1,935 \mathrm{~m}$ asl) were related to improved light conditions, which favored the submerged vegetation and therefore increased the diversity of the littoral habitat. Rautio (1998, 2001) suggested that the length of the growing season affects Cladocera via modifying the occurrence of macrophytes. Whiteside and Harmsworth (1967) and Whiteside and Swindoll (1988) suggested that the complexity of the littoral habitat is reflected in Chydorid diversity. The strong secondary gradients in the NT-Cladocera assemblages $\left(\lambda_{1} / \lambda_{2}\right.$ in Table 3$)$, which were not related to any measured environmental variable, are probably correlated with habitat structure. Hohensee, which had the highest sample scores along the unconstrained ordination axes in DCCA or CCA (Tables 3, 4), was found to have a well-developed macrophyte community covering almost the entire lake bottom (pers. observation).

Although shifts from planktonic to littoral Cladocera were used to reconstruct lake-level changes in northern-temperate kettle-hole lakes (Korhola et al., 2005), this does not necessarily mean that Cladocera assemblages are correlated with mean or maximum depth, area, or volume of the lakes (Hofmann, 1996; this study). Cladocera that cannot strictly be assigned to either planktonic or littoral species, such as Chydorus sphaericus, may distort any correlation between water depth and Cladocera assemblages (Müller, 1964). More importantly, Cladocera-based lake-level models are based on the observation that the extension of the littoral area, rather than mean or maximum depth, affects the ratio between planktonic and littoral Cladocera (Hofmann, 1998).

The growth of zooplankton may be constrained by the availability of carbon, calcium, and phosphorus (Urabe et al., 1997; Schulz \& Sterner, 1999). We found that the occurrence of Daphnia sp. in the NTlakes was associated with high DOC concentration. Hessen and Rukke (2000) suggested that a high seston carbon to phosphorus ratio in combination with low calcium could cause a marked reduction in production of Daphnia. This could shift the competitive advantage toward less phosphorus and calcium demanding species. Winder et al. (2001) reported that chlorophyll a and particulate organic carbon best separated lakes with Daphnia from lakes without.
Bos and Cumming (2003) proposed that nutrients affected Cladocera assemblages via changes in habitat structure. According to Hofmann (1986), the littoral Cladocera do not react to an increase in trophy until the decrease in transparency limits the growth of macrophytes. Sterner et al. (1993) and Plath and Boersma (2001) suggested that changes in nutrients alter food availability and modify Cladocera assemblages. Mixing causes re-suspension of nutrients (Catalan et al., 2002). Phosphorus and calcium concentrations affect the molting process (Hessen \& Rukke, 2000). Temperature, calcium, and phosphorus are therefore linked via build-up and loss of exuviae. Metabolic links may be reflected by the significant canonical correspondence axis 1 (Table 4) which summarized effects of climate and nutrients.

Besides climate, Cladocera are possibly affected by nutrient input from alpine pastures (e.g., Kamenik et al., 2000; Hausmann et al., 2002), as suggested by the presence of Bosmina longirostris, which is considered to be an indicator of eutrophic conditions (e.g., Harmsworth, 1968; Gąsiorowski \& Szeroczyńska, 2004). During summer, all lakes with B. longirostris had cows in their catchments.

PC-axis 3, which was used as index for alkalinity supply, significantly explained variation in the Cladocera assemblages that was independent from the climate-related PC-axis 1 (Table 4). Lotter et al. (1997) showed that lake-water calcium concentration, which was linked to bedrock mineralogy and vegetation cover, best explained variation in Cladocera assemblages from the Swiss Alps. Bedrock mineralogy, which was independent of altitude and hence air temperature, was also the primary factor controlling cation availability in the NT-lakes (Kamenik et al., 2001). pH appears to affect Cladocera diversity only at levels that lie below the minimum $\mathrm{pH}$ found in the NT-lakes (Manca \& Armiraglio, 2002).

\section{Cladocera-based climate reconstruction}

We found two distinctly different Cladocera assemblages in our study area that were characterized by the presence/absence of Bosminidae. The two assemblages were separated by a climate threshold. Commonly used inference models, such as weighted averaging or logistic regression, assume a unimodal species response along an environmental gradient; for reliable estimates of a species' optima and tolerance, 
samples should be evenly distributed along this environmental gradient (ter Braak \& Looman, 1986). Clearly, these assumptions are not fulfilled in our dataset.

Nevertheless, Cladocera may be valuable climate proxies. Shifts from assemblages with Bosminidae to assemblages without Bosminidae (and vice versa), observed in sediment cores taken along transects (e.g., different altitudes) that include climatic thresholds probably illustrate the direction and magnitude of climate change. The sensitivity of this approach would be determined by the spatial representation of lakes along the climate gradient. The Niedere-Tauern area appears to be suitable for such an approach, because the climate threshold is located near the center of the climate gradient (Fig. 1).

\section{Conclusions}

In mountain lakes, Cladocera appear to be primarily driven by climate-related variables. There seems to be a climate threshold which triggers changes in Cladocera assemblages. The link between Cladocera and climate may be direct (e.g., via changing metabolic rates) or indirect (e.g., via changes in habitat structure or food availability). If the link was indirect, climate-independent changes in nutrients, the acid-base balance, or habitat structure may cause artifacts in Cladocerabased climate reconstructions. In sum, we recommend Cladocera as a valuable tool for multi-proxy climate reconstructions. Study sites should be located near climate thresholds that are important for Cladocera.

Acknowledgments We would like to thank P. Indinger and numerous volunteers for their help in the field. H. Höllerer and J. Knoll for technical assistance, B. Franzoi and W. Müller for chemical analyses, G. Kum for lake surface-area measurements, three anonymous reviewers for helpful comments, J. Kaplan for correcting the English, and E. Slezak for her support while writing the manuscript. This study was funded by the Austrian Science Fund (FWF, project no. P14912-B06).

\section{References}

Barry, R. G., 2001. Mountain Weather and Climate. Routledge, London.

Battarbee, R. W., 2000. Palaeolimnological approaches to climate change, with special regard to the biological record. Quaternary Science Reviews 19: 107-124.
Battarbee, R. W., J. A. Grytnes, R. Thompson, P. G. Appleby, J. Catalan, A. Korhola, H. J. B. Birks, E. Heegaard \& A. Lami, 2002. Comparing palaeolimnological and instrumental evidence of climate change for remote mountain lakes over the last 200 years. Journal of Paleolimnology 28: 161-179.

Bennett, K. D., 1996. Determination of the number of zones in a biostratigraphical sequence. New Phytologist 132: $155-170$.

Birks, H. J. B., 1995. Quantitative palaeoenvironmental reconstructions. In Maddy, D. \& J. S. Brew (eds), Statistical Modeling of Quaternary Science Data. Technical Guide 5. Quaternary Research Association, Cambridge, 161-254.

Birks, H. J. B. \& A. D. Gordon, 1985. Numerical Methods in Quaternary Pollen Analysis. Academic Press, London.

Bos, D. G. \& B. F. Cumming, 2003. Sedimentary cladoceran remains and their relationship to nutrients and other limnological variables in 53 lakes from British Columbia, Canada. Canadian Journal of Fisheries and Aquatic Sciences 60: 1177-1189.

Bottrell, H. H., 1975. Generation time, length of instar, instar duration and frequency of moulting, and their relationship to temperature in eight species of Cladocera from the River Thames, Reading. Oecologia 19: 129-140.

Bradley, R. S., 2000. Past global changes and their significance for the future. Quaternary Science Reviews 19: 391-402.

Catalan, J., M. Ventura, A. Brancelj, I. Granados, H. Thies, U. Nickus, A. Korhola, A. F. Lotter, A. Barbieri, E. Stuchlík, L. Lien, P. Bitušík, T. Buchaca, L. Camarero, G. H. Goudsmit, J. Kopáćek, G. Lemcke, D. M. Livingstone, B. Müller, M. Rautio, M. Šiško, S. Sorvari, F. Šporka, O. Strunecký \& M. Toro, 2002. Seasonal ecosystem variability in remote mountain lakes: implications for detecting climatic signals in sediment records. Journal of Paleolimnology 28: 25-46.

Cummings, M. P., D. S. Myers \& M. Mangelson, 2004. Applying permutation tests to tree-based statistical models: extending the R package rpart. Technical Report CSTR-4581, UMIACS-TR-2004-24. Center for Bioinformatics and Computational Biology, Institute for Advanced Computer Studies, University of Maryland.

Dufrêne, M. \& P. Legendre, 1997. Species assemblages and indicator species: the need for a flexible asymmetrical approach. Ecological Monographs 67: 345-366.

Duigan, C. A., 1992. The ecology and distribution of the littoral freshwater Chydoridae (Branchiopoda, Anomopoda) of Ireland, with taxonomic comments on some species. Hydrobiologia 241: 1-70.

Duigan, C. A. \& H. H. Birks, 2000. The late-Glacial and earlyHolocene palaeoecology of cladoceran microfossil assemblages at Kråkenes, western Norway, with a quantitative reconstruction of temperature changes. Journal of Paleolimnology 23: 67-76.

Duigan, C. A. \& W. L. Kovach, 1991. A study of the distribution and ecology of littoral freshwater Chydorid (Crustacea, Cladocera) communities in Ireland using multivariate analyses. Journal of Biogeography 18: 267-280.

Flössner, D., 1972. Branchiopoda, Branchiura. Tierwelt Deutschlands 60: 1-501. 
Flössner, D., 2000. Die Haplopoda und Cladocera (ohne Bosminidae) Mitteleuropas. Backhuys Publishers, Leiden.

Frey, D. G., 1964. Remains of animals in Quaternary lake and bog sediments and their interpretation. Archiv für Hydrobiologie, Supplement Ergebnisse der Limnologie 2: $1-116$.

Frey, D. G., 1986. Cladocera analysis. In Berglund, B. E. (eds), Handbook of Holocene Palaeoecology and Palaeohydrology. John Wiley \& Sons, Chichester, 667-692.

Frey, D. G., 1988. Littoral and offshore communities of diatoms, cladocerans and dipterous larvae, and their interpretation in paleolimnology. Journal of Paleolimnology 1: 179-191.

Frey, D. G., 1991. First subfossil records of Daphnia headshields and shells (Anomopoda, Daphniidae) about 10,000 years old from northernmost Greenland, plus Alona guttata (Chydoridae). Journal of Paleolimnology 6: 193-197.

Goulden, C. E. \& D. G. Frey, 1963. The occurrence and significance of lateral head pores in the genus Bosmina (Cladocera). Internationale Revue der gesamten Hydrobiologie 48: 513-522.

Gąsiorowski, M. \& K. Szeroczyńska, 2004. Abrupt changes in Bosmina (Cladocera, Crustacea) assemblages during the history of the Ostrowite lake (northern Poland). Hydrobiologia 526: 137-144.

Harmsworth, R. V., 1968. The developmental history of Blelham Tarn (England) as shown by animal microfossils, with special reference to the Cladocera. Ecological Monographs 38: 223-241.

Hausmann, S., A. F. Lotter, J. F. N. van Leeuwen, C. Ohlendorf, G. Lemcke, E. Grönlund \& M. Sturm, 2002. Interactions of climate and land use documented in the varved sediments of Seebergsee in the Swiss Alps. The Holocene 12: 279-289.

Heiri, O., A. F. Lotter, S. Hausmann \& F. Kienast, 2003. A chironomid-based Holocene summer air temperature reconstruction from the Swiss Alps. The Holocene 13: 477-484.

Hessen, D. O. \& N. A. Rukke, 2000. The costs of moulting in Daphnia; mineral regulation of carbon budgets. Freshwater Biology 45: 169-178.

Hofmann, W., 1986. Developmental history of the Grosser Plöner See and the Schönsee (north Germany): cladoceran analysis, with special reference to eutrophication. Archiv für Hydrobiologie, Supplement 74: 259-287.

Hofmann, W., 1987. Cladocera in space and time - analysis of lake-sediments. Hydrobiologia 145: 315-321.

Hofmann, W., 1996. Empirical relationships between cladoceran fauna and trophic state in thirteen northern German lakes: analysis of surficial sediments. Hydrobiologia 318 : 195-201.

Hofmann, W., 1998. Cladocerans and chironomids as indicators of lake level changes in north temperate lakes. Journal of Paleolimnology 19: 55-62.

Hofmann, W., 2000. Response of the chydorid faunas to rapid climatic changes in four Alpine lakes at different altitudes. Palaeogeography, Palaeoclimatology, Palaeoecology 159: 281-292.

Hofmann, W., 2001. Late-Glacial/Holocene succession of the chironomid and cladoceran fauna of the Soppensee
(Central Switzerland). Journal of Paleolimnology 25: 411-420.

Hofmann, W., 2003. The long-term succession of high-altitude cladoceran assemblages: a 9,000-year record from Sägistalsee (Swiss Alps). Journal of Paleolimnology 30: 291-296.

Jackson, D. A., 1993. Stopping rules in principal components analysis: a comparison of heuristical and statistical approaches. Ecology 74: 2204-2214.

Jeppesen, E., J. P. Jensen, T. L. Lauridsen, S. L. Amsinck, K. Christoffersen, M. Sondergaard \& S. F. Mitchell, 2003. Sub-fossils of cladocerans in the surface sediments of 135 lakes as proxies for community structure of zooplankton, fish abundance and lake temperature. Hydrobiologia 491: 321-330.

Kamenik, C., K. A. Koinig, R. Schmidt, P. G. Appleby, J. A. Dearing, A. Lami, R. Thompson \& R. Psenner, 2000. Eight-hundred years of environmental changes in a high alpine lake (Gossenköllesee, Tyrol) inferred from sediment records. Journal of Limnology 59: 43-52.

Kamenik, C. \& R. Schmidt, 2005. Chrysophyte resting stages: a tool for reconstructing winter/spring climate from Alpine lake sediments. Boreas 34: 477-489.

Kamenik, C., R. Schmidt, G. Kum \& R. Psenner, 2001. The influence of catchment characteristics on the water chemistry of mountain lakes. Arctic, Antarctic and Alpine Research 33: 404-409.

Korhola, A., 1999. Distribution patterns of Cladocera in subarctic Fennoscandian lakes and their potential in environmental reconstruction. Ecography 22: 357-373.

Korhola, A. \& M. Rautio, 2001. Cladocera and other branchiopod crustaceans. In: Smol, J. P., H. J. B. Birks, \& W. M. Last (eds), Tracking Environmental Change Using Lake Sediments. Volume 4: Zoological Indicators. Kluwer Academic Publishers, Dordrecht, 5-41.

Korhola, A., M. Tikkanen \& J. Weckström, 2005. Quantification of Holocene lake-level changes in Finnish Lapland using a cladocera - lake depth transfer model. Journal of Paleolimnology 34: 175-190.

Legendre, P. \& L. Legendre, 1998. Numerical Ecology. Elsevier, Amsterdam.

Lepš, J. \& P. Šmilauer, 2003. Multivariate Analysis of Ecological Data Using CANOCO. Cambridge University Press, Cambridge.

Lotter, A. F. \& H. J. B. Birks, 2003. The Holocene palaeolimnology of Sägistalsee and its environmental history - a synthesis. Journal of Paleolimnology 30: 333-342.

Lotter, A. F., H. J. B. Birks, U. Eicher, W. Hofmann, J. Schwander \& L. Wick, 2000. Younger Dryas and Allerød summer temperatures at Gerzensee (Switzerland) inferred from fossil pollen and cladoceran assemblages. Palaeogeography, Palaeoclimatology, Palaeoecology 159: 349-361.

Lotter, A. F., H. J. B. Birks, W. Hofmann \& A. Marchetto, 1997. Modern diatom, cladocera, chironomid, and chrysophyte cyst assemblages as quantitative indicators for the reconstruction of past environmental conditions in the Alps. I. Climate. Journal of Paleolimnology 18: 395-420.

Lotter, A. F., H. J. B. Birks, W. Hofmann \& A. Marchetto, 1998. Modern diatom, cladocera, chironomid, and 
chrysophyte cyst assemblages as quantitative indicators for the reconstruction of past environmental conditions in the Alps. II. Nutrients. Journal of Paleolimnology 19: 443-463.

Lotter, A. F. \& S. Juggins, 1991. POLPROF, TRAN and ZONE: programs for plotting, editing and zoning pollen and diatom data. INQUA-Subcommission for the study of the Holocene Working Group on Data-Handling Methods, Newsletter 6: 4-6.

Manca, M. \& M. Armiraglio, 2002. Zooplankton of 15 lakes in the southern Central Alps: comparison of recent and past (pre-ca 1850 AD) communities. Journal of Limnology 61: 225-231.

Meijering, M. P. D., 1983. On the occurrence of 'arctic' Cladocera with special reference to those along the Strait of Belle Isle (Quebec, Labrador, Newfoundland). Internationale Revue der gesamten Hydrobiologie 68: 885-893.

Milecka, K. \& K. Szeroczyńska, 2005. Changes in macrophytic flora and planktonic organisms in Lake Ostrowite, Poland, as a response to climatic and trophic fluctuations. Holocene 15: 74-84.

Moberg, A., D. M. Sonechkin, K. Holmgren, N. M. Datsenko \& W. Karlen, 2005. Highly variable northern hemisphere temperatures reconstructed from low- and high-resolution proxy data. Nature 433: 613-617.

Müller, W. P., 1964. The distribution of cladoceran remains in surficial sediments from three northern Indiana lakes. Investigations of Indiana Lakes \& Streams 6: 1-63.

Plath, K. \& M. Boersma, 2001. Mineral limitation of zooplankton: stochiometric constraints and optimal foraging. Ecology 82: 1260-1269.

Rautio, M., 1998. Community structure of crustacean zooplankton in subarctic ponds - effects of altitude and physical heterogeneity. Ecography 21: 327-335.

Rautio, M., 2001. Zooplankton assemblages related to environmental characteristics in treeline ponds in Finnish Lapland. Arctic, Antarctic and Alpine Research 33: 289-298.

Sandøy, S. \& J. P. Nilssen, 1986. A geographical survey of littoral Crustacea in Norway and their use in paleolimnology. Hydrobiologia 143: 277-286.

Sarmaja-Korjonen, K. \& P. Alhonen, 1999. Cladoceran and diatom evidence of lake-level fluctuations from a Finnish lake and the effect of aquatic-moss layers on microfossil assemblages. Journal of Paleolimnology 22: 277-290.

Sarmaja-Korjonen, K., S. Kultti, N. Solovieva \& M. Valiranta, 2003. Mid-Holocene palaeoclimatic and palaeohydrological conditions in northeastern European Russia: a multiproxy study of Lake Vankavad. Journal of Paleolimnology 30: 415-426.

Schmidt, R., C. Kamenik, C. Kaiblinger \& M. Hetzel, 2004a. Tracking Holocene environmental changes in an alpine lake sediment core: application of regional diatom calibration, geochemistry, and pollen. Journal of Paleolimnology 32: 177-196.

Schmidt, R., C. Kamenik, H. Lange-Bertalot \& R. Klee, $2004 \mathrm{~b}$. Fragilaria and Staurosira (Bacillariophyceae) from sedi- ment surfaces of 40 lakes in the Austrian Alps in relation to environmental variables, and their potential for palaeoclimatology. Journal of Limnology 63: 171-189.

Schulz, K. L. \& R. W. Sterner, 1999. Phytoplankton phosphorus limitation and food quality for Bosmina. Limnology and Oceanography 44: 1549-1556.

Sterner, R. W., D. D. Hagemeier \& W. L. Smith, 1993. Phytoplankton nutrient limitation and food quality for Daphnia. Limnology and Oceanography 38: 857-871.

Stumm, W. \& J. J. Morgan, 1996. Aquatic Chemistry: Chemical Equilibria and Rates in Natural Waters. John Wiley \& Sons, Inc., New York.

Szeroczyńska, K., 1984. Analiza Cladocera w osadach niektórych jezior tatrzańskich (Results of examination of Cladocera remains in lacustrine sediments of Dolina Pięciu Stawów Polskich). Prace i Studia Geograficzne 5: 93-110.

Szeroczyńska, K., 1998a. Cladocera analysis in the Late-Glacial sediments of the Lake Gościąž, Central Poland. In: Ralska-Jasiewiczowa, M., T. Goslar, T. Madeyska, \& L. Starkel (eds), Lake Gościąž, Central Poland. A Monographic Study. W. Szafer Institute of Botany, Polish Academy of Sciences, Kraków, 148-158.

Szeroczyńska, K., 1998b. Palaeolimnological investigations in Poland based on Cladocera (Crustacea). Palaeogeography, Palaeoclimatology. Palaeoecology 140: 335-345.

Szeroczyńska, K., 2002. Human impact on lakes recorded in the remains of Cladocera (Crustacea). Quaternary International 95-96: 165-174.

ter Braak, C. J. F., 1987. The analysis of vegetation-environment relationships by Canonical Correspondence Analysis. Vegetatio 69: 69-77.

ter Braak, C. J. F. \& S. Juggins, 1993. Weighted Averaging Partial Least Squares Regression (WA-PLS): an improved method for reconstructing environmental variables from species assemblages. Hydrobiologia 269/270: 485-502.

ter Braak, C. J. F. \& C. W. N. Looman, 1986. Weighted averaging, logistic regression and the Gaussian response model. Vegetatio 65: 3-11.

ter Braak, C. J. F. \& P. Šmilauer, 2002. CANOCO reference manual and CanoDraw for Windows user's guide: software for canonical community ordination (version 4.5). Microcomputer Power, Ithaca NY, USA.

Thompson, R., C. Kamenik \& R. Schmidt, 2005. Ultra-sensitive Alpine lakes and climate change. Journal of Limnology 64: 139-152.

Urabe, J., J. Clasen \& R. W. Sterner, 1997. Phosphorus limitation of Daphnia growth: is it real? Limnology and Oceanography 42: 1436-1443.

Venables, W. N. \& B. D. Ripley, 2002. Modern Applied Statistics with S. Springer, New York.

Venables, W. N. \& D. M. Smith, 2002. An Introduction to R. Network Theory Ltd., Bristol.

Whiteside, M. C. \& R. V. Harmsworth, 1967. Species diversity in chydorid (Cladocera) communities. Ecology 48: 664-667.

Whiteside, M. C. \& M. R. Swindoll, 1988. Guidelines and limitations to cladoceran paleoecological interpretations. 
Palaeogeography, Palaeoclimatology, Palaeoecology 62: 405-412.

Williamson, C. E., O. G. Olson, S. E. Lott, N. D. Walker, D. R. Engstrom \& B. R. Hargreaves, 2001. Ultraviolet radiation and zooplankton community structure following deglaciation in Glacier Bay, Alaska. Ecology 82: 1748-1760.
Winder, M., M. T. Monaghan \& P. Spaak, 2001. Have human impacts changed Alpine zooplankton diversity over the past 100 years? Arctic, Antarctic and Alpine Research 33: 467-475.

Wright, S. P., 1992. Adjusted P-values for simultaneous inference. Biometrics 48: 1005-1013. 